Vol II. No. 2, Maret 2018, hlm. $96-102$

Available online at www.jurnal.una.ac.id/indeks/jmp

\title{
PERBEDAAN PENINGKATAN KEMAMPUAN KOMUNIKASI MATEMATIS SISWA SMP MELALUI PEMBELAJARAN KOOPERATIF DENGAN PEMBELAJARAN KONVENSIONAL
}

\author{
Nilam Sari \\ Universitas Quality Medan \\ Email :nilamsarie@gmail.com
}

\begin{abstract}
This study aims to determine: Is there a significant difference between improving students' mathematical communication skills through cooperative learning with conventional learning. This research is a quasi-experimental research (quasi experiment). The population of this study was the students of SMPN 1 Takengon and the samples were taken randomly by Cluster random sampling technique, selected 2 classes that will be used as experiment class and control class. The instrument used is a communication skill test. Statistical analysis of data was done by t-test analysis. The results showed that: there is no significant difference between improving students' mathematical communication ability through cooperative learning with conventional learning
\end{abstract}

Keywords: Mathematical Communication, Co-operative, Conventional

\begin{abstract}
Abstrak
Penelitian ini bertujuan untuk mengetahui : Apakah terdapat perbedaan yang signifikan antara peningkatan kemampuan komunikasi matematis siswa melalui pembelajaran kooperatif dengan pembelajaran konvensional. Penelitian ini merupakan penelitian kuasi eksperimen(eksperimen semu). Populasi penelitian ini siswa SMPN 1 Takengon dan sampel diambil secara acak dengan teknik Cluster random sampling, terpilih 2 kelas yang akan dijadikan kelas eksperimen dan kelas kontrol. Instrumen yang digunakan adalah tes kemampuan komunikasi. Analisis statistik data dilakukan dengan analisis uji-t. Hasil penelitian menunjukkan bahwa : tidak terdapat perbedaan yang signifikan antara peningkatan kemampuan komunikasi matematika siswa melalui pembelajaran kooperatif dengan pembelajaran konvensional.
\end{abstract}

Kata kunci : Komunikasi Matematika, Kooperatif, Konvensional

$\begin{array}{lll}\text { Matematika merupakan suatu } & \text { kreatif dan juga dapat menjadi individu } \\ \text { pelajaran yang dapat memberi } & \text { yang kompeten. Ansari (2009) } \\ \text { sumbangan untuk mengatasi rendahnya } & \text { menjelaskan bahwa "pembelajaran } \\ \text { kualitas sumber daya manusia Indonesia. } & \text { matematika bertujuan untuk } \\ \text { Karena dengan bermatematika individu } & \text { mengembangkan keterampilan dan } \\ \text { diharapkan mampu menyelesaikan } & \text { memandirikan individu dalam belajar } \\ \text { masalah-masalah yang kompleks, selain } & \text { berkolaborasi, melakukan penilaian diri }\end{array}$




\section{MATEMATICS PAEDAGOGIC}

Vol II. No. 2, Maret 2018, hlm. 96 - 102

Available online at www.jurnal.una.ac.id/indeks/jmp

(refleksi) serta mendorong individu membangun pengetahuannya sendiri".

Dengan bermatematika diharapkan dapat mengembangkan potensi anak didik, harapannya proses pendidikan haruslah berorientasi kepada siswa dan akhir dari proses pendidikan itu adalah berujung kepada peningkatan kemampuan peserta didik, pengembangan kecerdasan intelektual serta pengembangan ketrampilan anak sesuai dengan kebutuhan, sehingga diharapkan mampu mempersiapkan Sumber Daya Manusia (SDM) berkualitas sehingga dapat meningkatkan mutu pendidikan di Indonesia.

Kenyataannya yang terlihat dari hasil tes PISA (Programme for International Student Assesment) yang diselenggarakan pada tahun 2009 bertujuan untuk mengukur tingkat kemampuan komunikasi matematik siswa. Dari 65 negara yang ikut serta Indonesia berada pada peringkat 61, sedangkan Thailand (50), Australia (15), Kazastan (53), Jepang (9), Singapura (2) dan Shanghai-Cina (1). Data ini menunjukkan bahwa Negara kita, peringkat Indonesia baru bisa menduduki 10 besar terbawah dari 65 negara. Dengan predikat ini bisa mencerminkan bagaimana kemampuan komunikasi matematik siswa-siswa di Indonesia saat ini. Padahal menurut National Council of Teacher of Mathematics (NCTM, 1989) menyebutkan kemampuan dasar matematika meliputi kemampuan pemahaman, pemecahan masalah, penalaran, koneksi dan komunikasi.
Berdasarkan standar kompetensi yang termuat dalam kurikulum tersebut maka pembelajaran matematika di sekolah harus dapat menyiapkan siswa untuk memiliki kemampuan komunikasi matematik sebagai bekal untuk menghadapi tantangan perkembangan dan perubahan. Baroody (1993) menyebutkan sedikitnya ada dua alasan penting mengapa kemampuan komunikasi matematik perlu ditumbuhkembangkan dikalangan siswa. Pertama, mathematics as language, artinya matematika tidak hanya sekedar alat bantu berpikir (a tool to aid thinking), alat untuk menemukan pola, menyelesaikan masalah atau mengambil kesimpulan, tetapi matematika juga sebagai alat yang berharga untuk mengkomunikasikan berbagai ide secara jelas, tepat dan cermat. Kedua, mathematics learning as social activity; artinya, sebagai aktivitas sosial dalam pembelajaran matematika, matematika juga sebagai wahana interaksi antar siswa, dan juga komunikasi antara guru dan siswa.

Pada dasarnya rendahnya kemampuan komunikasi matematik siswa tidaklah terlepas dari cara guru menyampaikan materi pelajaran di kelas. Dengan kata lain, guru tidak memberikan kesempatan kepada siswa untuk mengkonstruksi pengetahuan matematika yang akan menjadi milik siswa. Dengan kondisi yang demikian, kemampuan komunikasi matematik siswa kurang berkembang, sehingga proses penyelesaian jawaban siswa terhadap permasalahan yang diajukan oleh gurupun tidak bervariasi. 


\section{MATEMATICS PAEDAGOGIC}

Vol II. No. 2, Maret 2018, hlm. 96 - 102

Available online at www.jurnal.una.ac.id/indeks/jmp

Oleh karena itu, pemilihan lingkungan belajar khususnya pendekatan pembelajaran menjadi sangat penting untuk dipertimbangkan artinya pemilihan pendekatan pembelajaran harus dapat mengakomodasi kemampuan matematika siswa yang heterogen sehingga dapat memaksimalkan hasil belajar siswa.

Sejalan dengan berkembangnya penelitian di bidang pendidikan maka ditemukan pendekatan pembelajaran baru yang dapat meningkatkan interaksi siswa dalam proses belajar mengajar, yang dikenal dengan pendekatan pembelajaran kooperatif. Pembelajaran kooperatif tipe Jigsaw merupakan salah satu tipe pembelajaran yang mendorong siswa aktif dan saling membantu dalam menguasai materi pelajaran untuk mencapai prestasi yang maksimal (Isjoni, 2010: 77). pembelajaran kooperatif tipe Jigsaw di desain untuk meningkatkan rasa tanggung jawab siswa terhadap pembelajarannya sendiri dan juga pembelajaran orang lain. Siswa tidak hanya mempelajari materi yang diberikan, tetapi mereka juga harus siap memberikan dan mengajarkan materi tersebut pada anggota kelompoknya.

Beberapa peneliti telah menunjukkan dampak positif dari penerapan pembelajaran koperatif diantaranya hasil penelitian Sribina (2011) pembelajaran kooperatif tipe TPS berbantuan software Autograph memberikan pemahaman siswa terhadap materi integral pada perhitungan luas daerah pada bidang datar beberapa kurva, di dukung oleh hasil penelitian Imelda (2011) pembelajaran kooperatif tipe TPS dengan media software Autograph membantu siswa menentukan bayangan transformasi. Berdasarkan hasil penelitian di atas peneliti berharap pembelajaran yang dilakukan melalui pembelajaran kooperatif tipe Jigsaw dapat membantu siswa lebih mudah mempelajari materi statistika.

Berdasarkan uraian latar belakang di atas, peneliti mencoba untuk menggunakan

pembelajaran kooperatif tipe Jigsaw, untuk meningkatkan kemampuan komunikasi matematika.

\section{METODE}

\section{Populasi dan Sampel Penelitian}

Populasi pada penelitian ini adalah seluruh siswa SMPN 1 Takengon. Sedangkan sampel penelitian terdiri dari 2 kelas (1 kelas sebagai kelompok eksperimen dan 1 kelas sebagai kelompok kontrol).

\section{Rancangan Penelitian}

Rancangan penelitian yang digunakan dalam penelitian ini adalah Pretes Posttest Control Group Design sebagai berikut.

Tabel 1: Rancangan Penelitian

\begin{tabular}{cccc}
\hline Kelas & Pretes & Treatment & Postes \\
\hline Eksperimen & $\mathrm{T}_{1}$ & $\mathrm{X}_{1}$ & $\mathrm{~T}_{2}$ \\
\hline Kontrol & $\mathrm{T}_{1}$ & $\mathrm{X}_{2}$ & $\mathrm{~T}_{2}$ \\
\hline
\end{tabular}

\section{Instrumen Penelitian}

Intrumen yang digunakan dalam penelitian ini adalah tes kemampuan komunikasi matematik. Tes terlebih 


\section{MATEMATICS PAEDAGOGIC}

Vol II. No. 2, Maret 2018, hlm. 96 - 102

Available online at www.jurnal.una.ac.id/indeks/jmp

dahulu divalidasi oleh beberapa ahli dan dilakukan uji coba lapangan. Hasil validitas dan reliabilitas dapat dilihat berikut ini:

Tabel 2: Hasil analisis ujicoba tes kemampuan komunikasi matematika

\begin{tabular}{|c|c|c|c|c|c|c|}
\hline \multirow{2}{*}{$\begin{array}{l}\text { No } \\
\text { Soal }\end{array}$} & \multicolumn{4}{|c|}{ Validitas Butir } & \multicolumn{2}{|c|}{ Reliabilitas } \\
\hline & $\boldsymbol{r}_{\text {hit }}\left(\boldsymbol{r}_{x y}\right)$ & $r_{t a b}$ & $\begin{array}{c}\text { Inter } \\
\text { prestasi }\end{array}$ & $\begin{array}{c}\text { Krite } \\
\text { ria }\end{array}$ & Nilai & $\begin{array}{c}\text { Inter } \\
\text { Presta } \\
\text { si }\end{array}$ \\
\hline 1 & 13,25 & \multirow{5}{*}{2,03} & $\begin{array}{c}\text { Sangat } \\
\text { tinggi }\end{array}$ & Valid & \multirow{5}{*}{0,66} & \multirow{5}{*}{ Tinggi } \\
\hline 2 & 9,45 & & $\begin{array}{l}\text { Sangat } \\
\text { tinggi }\end{array}$ & Valid & & \\
\hline 3 & 5,95 & & Tinggi & Valid & & \\
\hline 4 & 7,24 & & Tinggi & Valid & & \\
\hline 5 & 7,31 & & Tinggi & Valid & & \\
\hline
\end{tabular}

\section{Teknik Analisis Data}

\section{Menguji normalitas dan homogenitas kemampuan komu- nikasi matematika.}

2. Melakukan pengujian hipotesis; Terdapat perbedaan yang signifikan antara peningkatan kemampuan komunikasi matematika siswa melalui pembelajaran kooperatif dengan pembelajaran konvensional.

\section{HASIL DAN PEMBAHASAN}

Setelah dilakukan pretes dan postes kepada siswa diperoleh N-Gain masing-masing kelas untuk melihat perbedaan peningkatan komunikasi matematika kedua pembelajaran. Ratarata $\mathrm{N}$-Gain kemampuan komunikasi matematika kelas eksperimen 0,67 dan rata-rata $\mathrm{N}$-Gain kemampuan komunikasi matematika kelas kontrol 0,66. Untuk mengetahui adanya perbedaan yang signifikan antara peningkatan kemampuan komunikasi matematika siswa melalui pembelajaran kooperatif dengan pembelajaran kon-vensional digunakan uji t. Dari data kemampuan komunikasi matematika diketahui data berdistribusi normal dan homogen, dapat dilihat pada tabel berikut.

\section{Tabel 3: Hasil Uji Normalitas N-Gain Kelas Eksperimen dan Kelas Kontrol (Tests of Normality)}

\begin{tabular}{|c|c|c|c|c|c|c|c|c|}
\hline \multirow{2}{*}{\multicolumn{2}{|c|}{ Kelas }} & \multicolumn{3}{|c|}{ Kolmogorov-Smirnov ${ }^{\mathrm{a}}$} & \multicolumn{3}{|c|}{ Shapiro-Wilk } & \multirow{2}{*}{$\begin{array}{l}\text { Tar } \\
\text { af } \\
\text { Sig }\end{array}$} \\
\hline & & $\begin{array}{l}\text { Stati } \\
\text { stic }\end{array}$ & Df & $\begin{array}{c}\text { Sig } \\
\text {. }\end{array}$ & $\begin{array}{l}\text { Stati } \\
\text { stic }\end{array}$ & Df & Sig & \\
\hline NGain & Eksperi & .175 & 23 & .067 & .923 & 23 & .076 & 0.05 Normal \\
\hline & $\overline{\text { Kontrol }}$ & .102 & 24 & $.200^{*}$ & .922 & 24 & .065 & 0.05 Normal \\
\hline
\end{tabular}


Jurnal

\section{MATEMATICS PAEDAGOGIC}

Vol II. No. 2, Maret 2018, hlm. 96 - 102

Available online at www.jurnal.una.ac.id/indeks/jmp

\section{Tabel 4: Hasil Uji Homogenitas Varians N-Gain Kelas Eksperimen Dan Kelas Kontrol}

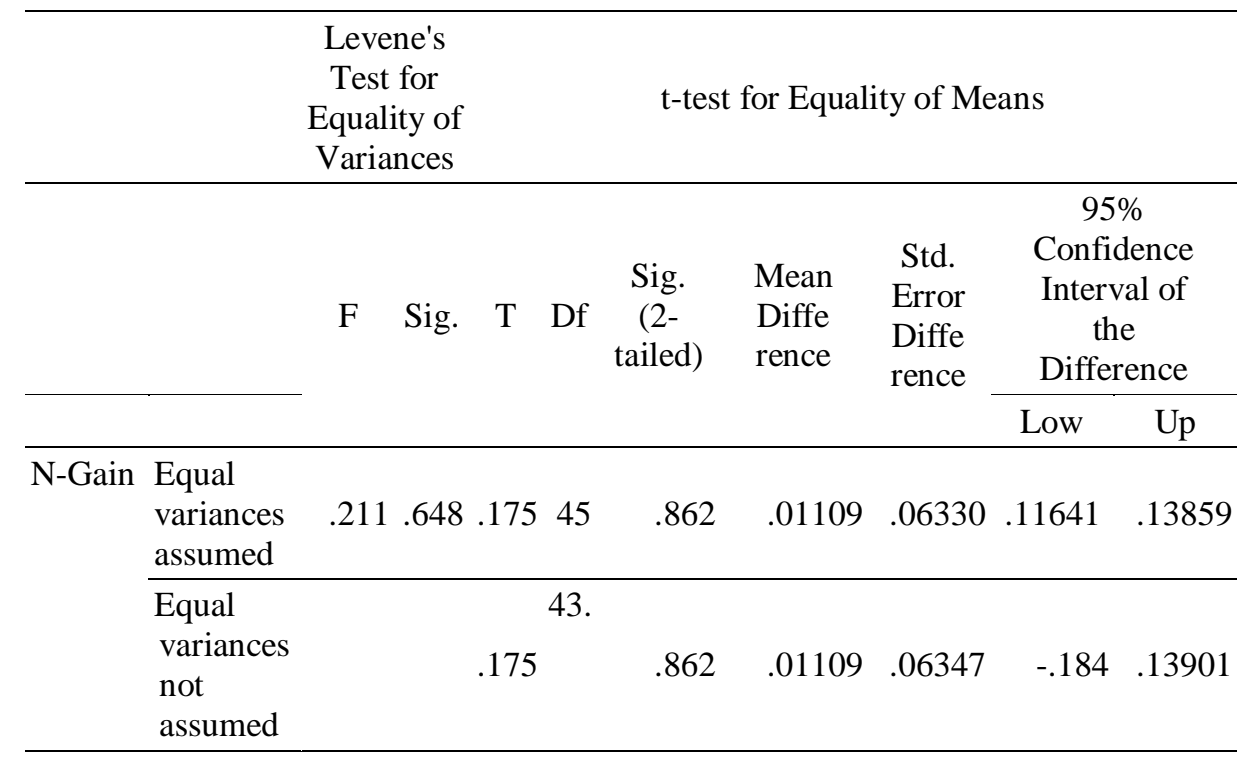

Tabel 5: Deskripsi Uji Perbedaan Rata Rata N-Gain Kemampuan Komunikasi Matematika Siswa

\begin{tabular}{|c|c|c|c|c|c|c|c|}
\hline & & $\begin{array}{c}\text { Levene } \\
\text { Stat }\end{array}$ & df1 & df 2 & Sig. & $\begin{array}{c}\text { Taraf } \\
\text { Sig }\end{array}$ & Ket \\
\hline \multirow[t]{4}{*}{ Ngai } & $\begin{array}{l}\text { Based on } \\
\text { I Mean }\end{array}$ & .211 & 1 & 45 & .648 & 0.05 & Homogen \\
\hline & $\begin{array}{l}\text { Based on } \\
\text { Median }\end{array}$ & .020 & 1 & 45 & .888 & & \\
\hline & $\begin{array}{l}\text { Based on } \\
\text { Median } \\
\text { and with } \\
\text { adjusted df }\end{array}$ & .020 & 1 & 40.849 & .889 & & \\
\hline & $\begin{array}{l}\text { Based on } \\
\text { trimmed } \\
\text { mean }\end{array}$ & .136 & 1 & 45 & .714 & & \\
\hline
\end{tabular}

Berdasarkan tabel di atas terlihat nilai signifikan lebih besar dari taraf signifikan 0,05 yaitu $0,86>0,05$ sehingga hipotesis nol diteima, jadi dapat disimpulkan bahwa tidak terdapat perbedaan yang signifikan antara peningkatan kemampuan komunikasi matematika siswa melalui pembelajaran kooperatif dengan pembelajaran konvensional. 


\section{MATEMATICS PAEDAGOGIC}

Vol II. No. 2, Maret 2018, hlm. 96 - 102

Available online at www.jurnal.una.ac.id/indeks/jmp

\section{SIMPULAN}

Tidak terdapat perbedaan peningkatan yang signifikan antara kemampuan komunikasi matematika siswa melalui pembelajaran kooperatif dengan pembelajaran konvensional.

\section{saran}

a. Bagi guru matematika

1. Guru berperan sebagai pendamping, memupuk tang-gung jawab, terus melakukan pemantauan, memfasilitasi diskusi kelompok baik yang dilakukan oleh kelompok ahli maupun kelompok asal. Dan bentuk pemimpin diskusi untuk menjamin kelangsungan diskusi secara teratur dan tertib sehingga peserta benar-benar mengambil bagian dalam diskusi.

2. Mengelompokkan siswa secara heterogen masing-masing ke-

\section{DAFTAR RUJUKAN}

Ansari, B.I. 2009. Komunikasi Matematik Konsep dan Aplikasi. Banda Aceh. Yayasan Pena.

Baroody, A.J. (1993). Problem Solving, Reasoning, and Kominicating, k-8. Healping Children Thing Mathematically. New York : Merril, an Inprint of Macmillan Publishing, Company.

National Council of Teacher of Mathematics. 1989. NCTM Curriculum and Evaluation Standards for school mathematics. [on-line]. lompok asal dan pemberian tugas sesuai dengan kemampuan siswa.

b. Kepada peneliti lanjutan

1. Sebaiknya melakukan penelitian pada sekolah yang memiliki fasilitas yang memadai. Perlu dilakukan penelitian yang berbeda, misalnya pada tingkat sekolah menengah pertama. Dengan materi dan populasi penelitian yang lebih banyak lagi.

2. Perlu diteliti lebih lanjut masalah pembelajaran kooperatif apakah juga berperan dalam meningkatkan kemampuan penalaran, problem solving dan koneksi matematik.

3. Sebaiknya waktu penelitian dilakukan tidak berdekatan dengan Ujian Nasional.

http://www.nctm.org/focalpoints [21 Juli 2011]

PISA. (2009). Programme for International Student Assesment. [Tersedia online] (http://p4mri.net/new/?p=338) [diakses 6 Pebruari 2012]

Imelda. 2011. Penerapan Model Pembelajaran Kooperatif Tipe Think-Pair-Share (TPS) dengan Media Software Autograph Untuk Meningkatkan Kemampuan Komunikasi dan Pemahaman Matematik Siswa. 
Jurnal

\section{MATEMATICS PAEDAGOGIC}

Vol II. No. 2, Maret 2018, hlm. 96 - 102

Available online at www.jurnal.una.ac.id/indeks/jmp

Tesis tidak diterbitkan. Medan:

Program Pascasarjana Unimed Medan.

Sribina, Nuraini. 2011. Perbedaan

Kemampuan Komunikasi

Matematis Siswa SMA melalui
Pembelajaran Kooperatif Tipe Think Pair Square Tanpa Autograph. Tesis tidak diterbitkan. Medan: Program Pascasarjana Unimed Medan 